\title{
Evaluation of the Inpatients Who Apply With High INR-Level Due to Warfarin Use- A Retrospective Descriptive Study
}

\author{
Warfarin Kullanımına Bağı Yüksek INR Düzeyi ile Başvuran Hastaların \\ Değerlendirilmesi: Tanımlayıcı Retrospektif Bir Çalışma
}

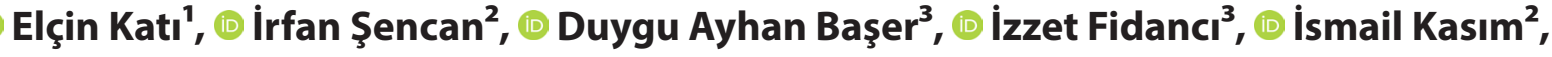 \\ Rabia Kahveci' ${ }^{2}$, Adem Özkara² $^{2}$ \\ 'Mamak Kıbrıs Family Health Center, Ankara, TURKEY \\ ${ }^{2}$ Ankara Numune Training and Research Hospital, Department of Family Medicine, Ankara, TURKEY \\ ${ }^{3}$ Hacettepe University, Faculty of Medicine, Department of Family Medicine, Ankara, TURKEY
}

\begin{abstract}
Aim: In this study, we aimed to evaluate the causes of mortality and their ability to benefit from primary health care facilities in patients receiving warfarin treatment and applying with high INR (international normalization ratio) values.

Material and Method: All patients who were admitted to our hospital for any reason, who had at least 4 INR and received warfarin treatment, were included in the study. The studies were analyzed retrospectively. The hospitalization epicrisis of 187 patients was evaluated. Questions were asked by phone about duration of warfarin use, follow-up frequency, primary health care status, changes in the floor made by the clinic, and the use of warfarin data.

Results: The study population consisted of 87 women and 100 men. The mean age of the patients was $64.1 \pm 17.6$ years. The most common hospitalization complaints in the whole population were bleeding (22.4\%), dyspnea (18.2\%), confusion (17.1\%) and nausea/ vomiting (9.6\%). INR level was above 10 in $34.2 \%$ of the patients. The highest indication of warfarin use was AF. Hypertension was the highest comorbidity. The predictors of mortality were chest pain ( $H R=3.808 ; p=0.012)$ and hemathesis ( $H R=3.688 ; p=0.033)$, respectively. The number of patients admitted to primary care for warfarin was 23 (12.3\%). Patients were followed up in cardiology, home health care, cardiovascular surgery and neurology $(16 \%$, $6.4 \%, 5.9 \%$, and $4.3 \%$, respectively). The rate of people who received warfarin training was $36.8 \%$.
\end{abstract}

Conclusion: Warfarin is a drug that requires frequent follow-up and complications are mortal. Patient education is very important and patients should be encouraged to use primary health care services, which are the most accessible health services.

Keywords: Bleeding, INR, mortality, primary health care, warfarin
Öz

Amaç: Bu çalışma ile warfarin tedavisi alan ve yüksek INR (uluslarası normalizasyon oranı) değerleri ile başvuran hastalarda mortaliteye etki eden nedenleri ve birinci basamak sağlık kuruluşlarından uygun olarak yararlanabilme durumlarını değerlendirmeyi amaçladık.

Gerec ve Yöntem: Herhangi bir nedenle warfarin tedavisi alan INR değeri 4 'ün üzerinde olan ve komplikasyon yaşayan 187 hasta çalışmamıza dahil edildi. Hastaların hastane epikrizlerinden hastane başvuru nedeni, hangi kliniğe başvurduğu, INR değerleri, komorbid hastalık varlığı, kan transfüzyonu ihtiyacı, tedavi sonrası sağlık durumu, warfarin endikasyonu, warfarin başlayan klinik retrospektif olarak değerlendirildi. Taburculuk durumu, warfarin kullanma süresi, takip sıklığı, birinci basamağa başvuru durumu, doz değişikliklerini hangi kliniğin yaptığı, eğitim durumu telefondan öğrenildi.

Bulgular: En sık hastaneye başvuru sebepleri kanama (\%22.4), dispne (\%18.2), ve kusma/bulantı (\%9.6) olarak belirlendi. Hastaların \%34.2'sinin INR değeri 10'un üzerindeydi. En sık warfarin başlama endikasyonu AF idi. Mortaliteye etki eden prediktörler göğüs ağrısı $(H R=3.808 ; p=0.012)$ ve hematemaz $(H R=3.688 ; p=0.033)$ olarak değerlendirildi. Birinci basamağa doz değișimi için başvuran hasta oranı \%12.3 idi. Hastaların takipleri en sık olarak kardiyoloji, evde sağlık hizmetleri, kardiyovasküler cerrahi ve nöroloji tarafından yapılmaktaydı (sırasıyla; \%16, \%6.4, \%5.9 ve \%4.3). Warfarin eğitimi alanların oranı ise \%36.8 idi.

Sonuç: Warfarin sık takip gerektiren ve komplikasyonları mortal olan bir ilaç olduğu için hasta eğitimi çok önemlidir ve hastaların en kolay ulaşabilecekleri sağlık hizmeti olan birinci basamak sağlık hizmetlerini kullanmaları yönünde teşvik edilmesi gerekmektedir.

Anahtar Kelimeler: Kanama, INR, mortalite, birinci basamak sağlık hizmetleri, warfarin

Corresponding (illetişim): İzzet FiDANCl, Hacettepe University, Faculty of Medicine, Department of Family Medicine, Ankara, TURKEY

E-mail (E-posta): izzetfidanci@gmail.com

Received (Geliş Tarihi): 08.05.2020 Accepted (Kabul Tarihi): 27.05.2020 


\section{INTRODUCTION}

Thrombotic diseases are the most frequent group of diseases that cause death at present time. In the United States, two million people from six million people affected by thrombotic events die each year. ${ }^{[1,2]}$ Thrombosis occurs as a result of the process in the coagulation system, which begins with the deterioration of vascular integrity. Venous thrombosis most commonly ends up as pulmonary thromboembolism; arterial thrombosis results in as myocardial infarction, stroke and extremity gangrene. When considered how deadly the consequences of thrombotic event are, it shows obviously that prophylaxis and also treatment are so important. The drugs in treatment are three groups as anticoagulants (AC), antithrombocytes and thrombolytics. Among them, the most commonly used AC drugs are unfractionated heparin, standard heparin, and low molecular weight heparin (LMWH) and coumarin derivatives, warfarin..$^{[3]}$ Warfarin prevents the activation of coagulation factors and prevents clotting. Warfarin's teropatic interval is narrow and its efficacy is defined by the value of the international normalization ratio (INR). ${ }^{[4-6]}$ In the early stages of warfarin use INR follow-ups are frequent, but these intervals are expanded over time. In long term side effects begin to emerge by the influence of patient related risk factors. ${ }^{[7,8]}$ The most important side effect of warfarin is bleeding and its ratio varies percent $12-40$. Bleeding ratios are found in the nose (35\%), soft tissue (21\%), gastrointestinal system (15\%), urinary system (15\%), intracranial (4\%), thorax (3\%), intraocular (2\%), retroperitoneal (1\%). ${ }^{[9]}$

In last 30 years, big developments are recorded in the field of family medicine in our country. The position of the family medicine, which is one step ahead from other departments with its protective and coordinating features, in order to follow the diseases with high mortality and morbidity which require coordination of many units such as thrombosis, cannot be denied. Especially in today's condition where home health care services, which family doctors work mostly at, become widespread, the active participation of family physicians at managing indications and contraindications for thrombosis treatment and complications, requesting coagulation tests, interpreting, anticoagulation treatment-follow up and their interventions in these areas are very important. The purpose of our work; to examine the reasons for admission of patients whose INR value 4 and above and use warfarin and to evaluate the primary follow-up status of these patients. Our secondary purpose is to increase awareness for thrombotic diseases and treatment in the primary care services with the results of this study, and to plan training if necessary.

\section{MATERIAL AND METHOD}

Our study is designed as the retrospective descriptive type. The study was approved by the local ethics committee at Ankara Numune Training and Research Hospital prior study (IRB number: 2014-236, date: 16.07.2014). Our study includes all patients admitted to the Ankara Numune Training and Research Hospital between November 1, 2012 and October 31,2013 , for warfarin treatment and for at least 4 of the INR (International Normalization Ratio) values and who were admitted to our hospital. Hospitalized clinics were identified as Neurology, Cardiology, Intensive Care Service, Cardiovascular Surgery (CVS), Gynecology (G), Hematology, Urology, Anesthesia, Intensive Care Service, Emergency Internal Service (EIMS) and other services. In our hospital, there is no chest diseases service; patients who need to be hospitalized for pulmonary diseases were admitted to emergency internal medicine service.

The patient's name, surname, admission number, age, telephone, and gender of the 187 patients who had been hospitalized with any complications from 6108 patients with an INR greater than 4 determined from the hospital data center were reached. 187 hospitalized patient epicrisis were reviewed and it was learned which clinic referral complaint, which clinic is applied, which warfarin use status, INR value, comorbid diseases, blood transfusion need, treatment end point, warfarin use indications, which clinics started warfarin. In our hospital, 116 patients (71 in-hospital exitus) who were discharged from the hospital were contacted by telephone and were questioned to determine the duration of warfarin use, follow-up frequency, primary care application status, and whether they had been trained to use warfarin. No information was received from 43 of the 116 patients who did not have telephone numbers, who did not give information, did not answer the phone, and who were ex-patients after discharge from our hospital. Although the contact information of 73 patients was available, 5 patients could not be reached from the contact information, and as a result, 68 patients could be reached.

Statistical analysis was performed by using the Statistical Package for Social Sciences (SPSS) 20 program. The normal distribution of the numerical data was assessed by the Kolmogorov-Smirnov test. Numerical variables with normal distribution are shown as mean \pm standard deviation and numerical variables with no normal distribution are shown as median (min-max). Categorical variables were stated as number (\%). Comparison of normal distribution of numerical variables between two groups was done by $\mathrm{T}$ test in independent samples and ANOVA test in comparison between three or more groups. The Mann-Whitney $U$ test was used to compare non-normal numerical variables between two groups, and the Kruskall Wallis $\mathrm{H}$ test was used to compare three or more groups. Chi-square, Fisher's exact Chi-square test and Monte Carlo Simulation test were used to compare categorical data. Backward method of cox regression analysis was used to determine the risk factors that might affect mortality. Survival graphs were shown with Kaplan-Meier. In analyzes $p<0.05$ value was accepted as statistically significant. 


\section{RESULTS}

\section{Demographic features}

The study population consisted of 187 patients ( 87 females and 100 males). The mean age of male patients was $67.2 \pm 16.96$ years and the mean age of women patients was $60.6 \pm 17.6$. The median of INR level for the whole population was 7.9 (min:4.5; max:19.8). While INR levels do not differ statistically between genders $(p=0.138)$; there was a statistically significant difference according to age $(p=0.040)$. The most common comorbid diseases in patients are hypertension in $39 \%$, diabetes mellitus in $13.5 \%$, and COPD in $13.9 \%$. In $31.6 \%$ of patients it was determined blood transfusion (Fresh frozen plasma) is done. The demographic characteristics of the patients are shown in Table 1.

\section{Patient Hospitalization Characteristics and Mortality States}

While the hospital complaints did not show any significant difference according to sex $(p=0.953)$, the most common complaints were determined as dyspnea (18.2\%), consciousness blurring (17.1\%) and nausea / vomiting. The most frequent admission clinics in the hospital were the EIMS, the intensive care unit and the cardiology service. The inhospital mortality rate was $38 \%$.

\section{Starting Clinic and Indications of Warfarin}

Indications for induction of warfarin and starting clinics of 134 patients whose records are available are given in Table 2. It was determined that warfarin induction indications $(p=0.323)$ and warfarin starting clinics $(p=0.191)$ did not statistically affect patients' discharge or exitus status.

\begin{tabular}{|c|c|c|c|}
\hline Whole population $(n=187)$ & Women $(n=87)$ & Men $(n=100)$ & $\mathbf{p}$ \\
\hline $86(46.0)$ & $47(54.0)$ & $39(39.0)$ & $0.040^{*}$ \\
\hline $7.9(4.5-19.8)$ & $(4.5-18.6)$ & $8.6(5.1-19.8)$ & 0.138 \\
\hline $123(65.8)$ & $63(72.4)$ & $60(60.0)$ & 0.081 \\
\hline $20(10.7)$ & $10(11.5)$ & $10(10.0)$ & \\
\hline $73(39)$ & $36(41.4)$ & $37(37)$ & 0.552 \\
\hline $44(23.5)$ & $20(23)$ & $24(24)$ & 0.871 \\
\hline $26(13.9)$ & $9(10.3)$ & $17(17)$ & 0.21 \\
\hline 18(9.6) & $11(12.6)$ & $7(7)$ & 0.22 \\
\hline $21(11.2)$ & $6(6.9)$ & $15(15)$ & 0.104 \\
\hline $3(1.6)$ & $0(0)$ & $3(3)$ & 0.25 \\
\hline 59(31.6) & $26(29.9)$ & $33(33)$ & 0.753 \\
\hline
\end{tabular}

\begin{tabular}{|c|c|c|c|c|c|c|}
\hline Variables & Discharged & Ex & $\mathbf{p}$ & Women & Men & $\mathbf{p}$ \\
\hline $\mathrm{AF}$ & $44(45.8)$ & $13(34.2)$ & \multirow{6}{*}{0.323} & $21(36.2)$ & $36(47.4)$ & \multirow{6}{*}{0.301} \\
\hline CVD & $13(13.5)$ & $11(28.9)$ & & $12(20.7)$ & $12(15.8)$ & \\
\hline PTE & $9(9.4)$ & $2(5.3)$ & & $3(5.2)$ & $8(10.5)$ & \\
\hline DVT & $10(10.4)$ & $4(10.5)$ & & $8(13.8)$ & $6(7.9)$ & \\
\hline $\mathrm{PAH}$ & $1(1.0)$ & $1(2.6)$ & & $2(3.4)$ & - & \\
\hline Stent & $1(1.0)$ & - & & $1(1.7)$ & - & \\
\hline Starting Clinic & $n=94$ & $n=38$ & \multirow{4}{*}{0.191} & $n=94$ & $n=38$ & \multirow{4}{*}{0.572} \\
\hline Neurology & $12(12.8)$ & $10(26.3)$ & & 10(17.9) & $12(15.8)$ & \\
\hline Cardiology & $55(58.5)$ & $16(42.1)$ & & $28(50.0)$ & $43(56.6)$ & \\
\hline CVS & $21(22.3)$ & $8(21.1)$ & & $15(26.8)$ & $14(18.4)$ & \\
\hline
\end{tabular}


Patients with hemorrhage were found to have indications of AF in $52.4 \%$,valve replacement in $7.1 \%$, CVD in $12.9 \%$, DVT in $9.5 \%$, bypass in $4.8 \%$, PAH in $2.4 \%$, but the type of indication was not statistically significant compared to non-hemorrhage group ( $\mathrm{p}=0.070$ ).

Patients with an INR level above 10 were found to have indications of AF in $39.4 \%$, valve replacement in $18.2 \%$, CVD in $12.1 \%$, PTE in $3.0 \%$, DVT in $15.2 \%$, pace in $6.1 \%$, the bypass in $3 \%$, and $\mathrm{PAH}$ in $3 \%$.

When examining the clinics where warfarin is started; the proportion of patients in the cardiology clinic was higher in patients with hemorrhage compared to those without hemorrhage, but it was not statistically significant, in the group with INR level above 10, the proportion of patients in the CVS clinic was high but not statistically significant.

Age, geriatric age, sex and presence of comorbidity did not differ significantly between patients with INR levels of 10 and below compared to patients above 10 ( $p>0.05$ ).

The proportion of patients who had blood transfusion in patients with an INR level above $10(40.6 \%)$ was statistically significant higher than those with INR levels between 4.5 and $10(26 \%)(p=0.044)$. Complaints of admission to patients with INR levels above or below 10 did not differ statistically significant. Although the rate of exitus (42.3\%) was higher in patients with an INR level of 10 or less, it was statistically insignificant compared to patients with an INR level higher than $10(29.7 \%)$. The duration of hospitalization and the duration of warfarin use were close in both groups.

The mean age of the patients with in-hospital died (68.3 \pm 15.2$)$ was significantly higher than those discharged (61.6 \pm 18.5$)$ $(p=0.011)$. Also, median INR level (9.0) was statistically significantly higher in discharge patients compared to those who had died (7.0) ( $p=0.034)$. The proportion of patients with comorbidities and blood transfusion did not differ significantly between the patients with discharge and died ( $p>0.05$ ).

Although admission complaint varies according to mortality; ( $4.8 \%$ vs. $5.6 \%)$, routine control (5.2\% vs. $2.8 \%)$, nose bleeding $(4.3 \%$ vs. $4.8 \%)$, vaginal bleeding $(4.3 \%$ vs. $1.4 \%)$, bruise $(4.3 \%$ vs. $0 \%)$ and $(3.4 \%$ vs. $0 \%)$ visual loss were higher in the discharge group. Confusion (10.3\% vs. $28.2 \%$ ), dyspnea (15.5\% vs. $22.5 \%)$, nausea / vomiting ( $7.8 \%$ vs. $12.7 \%)$, melena ( $4.3 \%$ vs. $7 \%$ ) and hematemesis (3.4\% vs. $4.2 \%$ ) were higher in the group with exitus. When the hospitalized clinics are examined; it was found that the majority of discharged patients were admitted to EIMS (45.7\%) and cardiology (13.8\%) services, while the majority of patients who died had admission to intensive care (43.7\%) and EIMS (23.9\%).

\section{Predicting Factors In-hospital Mortality}

Step wise cox regression analysis was used to determine the risk factors that might affect on in-hospital mortality. Age, sex, INR value, comorbidity(hypertension, DM, COLD, CHF, renal failure, hematological disease, others), blood transfusion, complaints of hospitalization (hematuria, melena, hematemesis, nose bleeding, vaginal bleeding, unconsciousness, dizziness, chest pain, bruxism, suicide, diminished vision, routine control, shortness of breath, other factors) got involved in regression model. Chest pain and haematemesis which were complaints of hospitalization were found to be predictors of increased risk of in-hospital mortality. It was found that the risk of death was 3.808 times at patients with chest pain higher than those without chest pain, and 3.688 times more risk of death at patients with hematemesis than those without hematemesis complaints (It is not forgotten that there may be many different causes of chest pain.).

\section{Controls after Discharge}

After the discharge, control information of 68 patients was reached. We have not detected control findings of patient who did not give contact information, respond to phone and not give information about it. The median duration of warfarin use was 36 months, with a minimum of 2 months and a maximum of 156 months. The control frequencies of the control patients and the clinics where the dose change is provided are given in Table 3.

\begin{tabular}{lc} 
Table 3. Controls after discharge & \\
Usage time of Warfarin & $\mathbf{3 6 ( 2 - 1 5 6 ) \text { months }}$ \\
\hline Control & $7(10.3)$ \\
Irregularly & $2(2.9)$ \\
Once a week & $9(13.2)$ \\
Once every 15 days & $26(38.2)$ \\
Once a month & $21(30.9)$ \\
Once every 3 months & $3(4.4)$ \\
Unchecked & \\
\hline Clinics which change dosages & $8(11.8)$ \\
Neurology clinics & $30(44.1)$ \\
Cardiology clinic & $11(16.2)$ \\
CVS clinic & $12(17.6)$ \\
Home health service & $7(10.3)$ \\
Unchecked &
\end{tabular}

\section{DISCUSSION}

Warfarin is a widely used anticoagulant drug for both therapeutic and prophylactic purposes. In the amounts used, the balance between plasma warfarin level and its side effects should be well established. ${ }^{[10]}$ Problems may arise for patients when usage of warfarin, which is used for many diseases and has many indications, is not controlled or spontaneously. For this reason, besides the risks of using warfarin in patients who started warfarin treatment, the risks of use should be taken into account during treatment. It is most importance that patients be called to follow and trained in regular follow-up clinics in order to minimize these complications that may develop under warfarin therapy. ${ }^{[11]}$ 
It is known that age is an important parameter when the frequency of increasing comorbidities in geriatric age is considered. In our study, the geriatric patient population was $54 \%$. The risk associated with warfarin use may vary depending on the comorbidities and age of the patient and the patient. There are several studies evaluating the relationship between warfarin complications and age. Studies have shown that the incidence of hemorrhage complications due to high warfarin dose with the possibility of being seen at all ages is higher in patients over 50 years of age. ${ }^{[12]}$ In the study of Wallvik J et al. ${ }^{[13]}$ which included 195 major bleeding cases from 2701 patients followed by a 5 -year period in northern Sweden. They reported that there was 2.9 fold increase in risk in patients aged $60-69$ years; 4.8 fold increase in patients aged $70-79$ years; 6.6 fold increase risk in patients aged 80 and over in bleeding probability. In our study, there was no relationship between both increased age and geriatric age group and bleeding. In addition, although the mean age was high in the dying patients, neither the increased age nor the geriatric age was found to be an effective factor in the regression analysis aimed at revealing the in-hospital mortality risk. This suggests that the increased incidence of comorbidities with increasing age and the associated drug use may have a more effective role in the interaction with warfarin.

The role of gender should be discussed in relation to bleeding complication of warfarin. Some studies say that it is important to be a woman or a man, and some studies say that gender is not important. ${ }^{[14,15]}$ Female sex at the study of Shireman et al. ${ }^{[16]}$ male sex at the study of Lindh et al. ${ }^{[17]}$ and no gender at others' study as like our study is reported as a risk factor. In our study, gender was found to have no effect on both hemorrhage and mortality. ${ }^{[18-20]}$

When we considered on the indications of warfarin use in our study, patients were predominantly using warfarin due to atrial fibrillation. The most frequent indication for use in similar studies, including in our study, was reported as $\mathrm{AF}^{[21,22]}$

Makris et al. ${ }^{[23]}$ reported that hypertension, history of previous Gl bleeding, and the presence of previous cerebrovascular events have been associated with high risk of bleeding. Some studies reported that major bleeding was particularly prominent in patients with ischemic cerebrovascular disease and venous thromboembolism, and that the most important risk factors were hypertension, ulcer, cancer, previous surgical interventions. ${ }^{[24,25]}$ In our study, we reported that the most common accompanying diseases were hypertension, DM, COPD and renal failure, but the comorbidity and indications were not related to bleeding.

In literature, when the percentage of bleeding according to INR level was examined, studies showed no linear relationship between INR value and bleeding complication. ${ }^{[4-6]}$

Lindh et al. ${ }^{[17]}$ study identified a 46 -fold increased risk of bleeding complications for every 1.0 increase over the target INR. In another study, there was no linear correlation between
INR value and bleeding complication. ${ }^{[26]}$ In our study, it was also found that there was no relationship between high INR level and bleeding.

In our study; it is a very important finding that none of the diabetes, heart failure and other comorbidities questioned with hypertension makes a statistically significant difference with the INR levels. Because, except for the period of acute attacks of these diseases; it can be assumed that the agents used for treatment have increased the risk of bleeding except themselves.

Although we did not find any significant association between bleeding and comorbidities in our study, the association with the use of warfarin suggests that additional drug use may be responsible for bleeding. In a study; drug interactions play a role in the $43.5 \%$ of the development of warfarin-induced bleeding. ${ }^{[27]}$ For this reason, patients should be adequately informed about the use of warfarin, educated and regularly called for control.

In some studies, it was seen that the patients who were trained returned with fewer complications and were more compatible. ${ }^{[28,29]}$ For this reason, anticoagulation clinics or units have been established in developed countries like America. Warfarin selfmonitoring has been initiated in some countries, especially in countries such as Germany and the Netherlands; they started to make home controls with home type coagulometers. Even in some studies, home-type coagulometer and self-monitoring have been at least as successful as anticoagulation clinics. ${ }^{[30,31]}$ When we looked at Turkey, although many universities prepared booklets which are for educating patients about usage of warfarin, it was not seen enough. Especially in the South eastern Anatolia and Eastern Anatolia regions, low literacy rates indicate the necessity of education clinics or units. In the study done by Baydın et al. ${ }^{[32]}, 41 \%$ of the cases were uneducated and $51.2 \%$ were primary school graduates. In our study, although not statistically significant, it is an important result that all patients who die are uneducated. These shows how important education is to patients using warfarin.

It is extremely important that individuals who use warfarin move alongside a note (identity/document wristband) indicating that they are using medication. ${ }^{[3,34]}$ In our study, $63.2 \%$ of the cases indicated that they did not receive warfarin training. This shows that not only in the family medicine, but in the other clinics where warfarin is most frequent, there is a lack of patient education. These findings indicate that events require training in the use of warfarin and identification/ documentation or wristbands.

In our study although $33.8 \%$ of patients who came for controlling applied for primary care, any patients did not apply for changing dosage, its reason may be that INR value is not measured in primary care center at Turkey. It was determined that $17.6 \%$ of the patients who were given dose replacement received home health care service. The 
importance of primary health care services in our country has been understood in time and required importance has been given. Early detection, appropriate treatment and regular checks of chronic diseases have been required with the spread of chronic diseases and related deaths. As seen in our study, medical errors or omissions encountered in anticoagulation therapy cause high complication in the patient and result in death. Nowadays, physicians working in primary health care services have great duties for this reason. In home health care services which are updated and get new shaped, the role of primary care physicians is important.

The goal of this study is to increase the knowledge and awareness of primary care physicians about the clinical followup of patients in the home health care setting. Home health services are aimed to provide all kinds of health care services that are needed in bed-dependent and difficult-to-reach hospitals. Primary care physicians are the most important part of this service. The role of these physicians are very important at cooperation and communication with different disciplines, role of providing a comprehensive service and increasing quality of life, and they need the guidelines to be prepared in this area and to be more informed with these guides.

\section{ETHICAL DECLARATIONS}

Ethics Comittee Approval: The study was carried out with the permission of Ankara Numune Training and Research Hospital Ethics Committee (Permission granted.16.07.2014, Decision No. 2014-236).

Informed Consent: Because the study was designed retrospectively, no written informed consent form was obtained from patients.

Status of Peer-review: Externally peer-reviewed.

Conflict of Interest Statement: The authors have no conflicts of interest to declare.

Financial Disclosure: The authors declared that this study has received no financial support.

Author Contributions: All of the authors declare that they have all participated in the design, execution, and analysis of the paper, and that they have approved the final version.

\section{REFERENCES}

1. Fareed J, Hoppensteadt DA, Bick RL. An update on heparins at the beginning of the new millennium. Semin Thromb Hemost 2000;26(1):521.

2. Hoffman M, Monroe DM. 3rd, A cell-based model of hemostasis. ThrombHaemost 2001;85(6):958-65.

3. Feinstein DL, Akpa BS, Ayee MA, et al. The emerging threat of superwarfarins: history, detection, mechanisms, and countermeasures. Ann N Y Acad Sci 2016;1374(1):111-22.

4. Palareti G, Antonucci E, Mastroiacovo D, et al. The American College of Chest Physician score to assess the risk of bleeding during anticoagulation in patients with venous thromboembolism. J Thromb Haemost 2018;16:1994-2002.
5. Oprita R, Oprita B, Diaconescu B, Bratu MR, Berceanu D. Upper gastrointestinal endoscopy in emergency setting for patients receiving oral anticoagulants-practice updates. J Med Life 2017;10(1):27-32.

6. Walters KJ, Meador A, Galdo JA, Ciarrocca K. A pharmacotherapy review of the novel, oral antithrombotics. Spec Care Dentist 2017;37:62-70.

7. Wang K, van Es N, Cameron C, et al. Extended treatment of venous thromboembolism: a systematic review and network meta-analysis. Heart 2019;105:545-52.

8. Witt DM, Delate T, Clark NP, et al. Outcomes and predictors of very stable INR control duringchronic anticoagulation therapy. Blood 2009;114(5):952-6.

9. Geller Al, Shehab N, Lovegrove MC, et al. Emergency visits for oral anticoagulant bleeding. J Gen Intern Med 2020;35:371-3.

10. Anthony CJ, Karim S, Ackroyd-Stolarz S, et al. Intensity of anticoagulation with warfarin and risk of adverse in patients presenting to the emergency department. Ann Pharmacother 2011;45(7-8):881-7.

11. Eroğlu S, Denizbaşı AA, Özpolat Ç, Akoğlu H, Onur ÖO, Ünal EA. Varfarin kullanım öyküsü olan hastalarda, INR değerleriyle komplikasyon gelişim risk ilişkisinin ortaya konması. Marmara Medical J 2012;25:138-42.

12. Dahal K, Kunwar S, Rijal J, Schulman P, Lee J. Stroke, major bleeding, and mortality outcomes in warfarin users with atrial fibrillation and chronic kidney disease: a meta-analysis of observational studies. Chest 2016;149(4):951-9.

13. Wallvik J, Själander A, Johansson L, Bjuhr Ö, Jansson JH. Bleeding complications during warfarin treatment in primary healthcare centres compared with anticoagulation clinics. Scand J Prim Health Care 2007;25(2):123-8.

14. Ellison J, Thomon AJ, Greer IA, Walker ID. Apparent interaction between warfarin and levonorgestrel used for emergency contraception BMJ 2000;321:1382.

15. Ebell MH. Predicting the risk of bleeding in patients taking warfarin. Am Fam Physician 2010;81(6):780.

16. Shireman TI, Mahnken JD, Howard PA, Kresowik TF, Hou Q, Ellerbeck EF Development of a contemporary bleeding risk model for elderly warfarin recipients. Chest 2006;130(5):1390-6.

17. Lindh JD, Holm L, Dahl ML, Alfredsson L, Anders Rane A. Incidence and predictors of severe bleeding during warfarin treatment. J Thromb Thrombolysis 2008;25(2):151-9.

18. Bussey HI, Rospond RM, Quandt CM, Clark GM. The safety and effectiveness of long-term warfarin therapy in an anticoagulation clinic. Pharmacotherapy 1989;9(4):214-9.

19. Mcmahon D. Risk of major hemorrhage for outpatients treatment with warfarin. J Gen Intern Med 1998;13:311-6.

20. Levine MN, Raskob G, Landefeld S, Kearon C. Hemorrhagic complications of anticoagulant treatment. Chest 2001;119:108-21.

21. Fanikos J, Grasso-Correnti N, Shah R, Kucher N, Goldhaber SZ. Major bleeding complications in a specialized anticoagulation service. Am J Cardiol 2005;96(4):595-8.

22. Koo S, Kucher N, Nguyen PL, Fanikos J, Marks PW, Goldhaber SZ. The effect of excessive anticoagulation on mortality and morbidity in hospitalized patients with anticoagulant-related major hemorrhage. Arch Intern Med 2004;164(14):1557-60.

23. Makris M, Watson HG. The management of coumarin-induced over anticoagulation Annotation. Br J Haematol 2001;114(2):271-80.

24. Stanton BE, Barasch NS, Tellor KB. Comparison of the safety and effectiveness of apixaban versus warfarin in patients with severe renal impairment. Pharmacotherapy 2017;37:412-9.

25. Levine LN, Raskob G, Beyth RJ, Kearon C, Schulman S. Hemorrhagic complications of anticoagulant treatment: the seventh ACCP conference on antithrombotic and thrombolytic therapy. Chest 2004;126(3):287-310.

26. Ridker PM, Goldhaber SZ, Danielson E, et al. Long-term, lowintensity warfarin therapy for the prevention of recurrent venous thromboembolism. N Engl J Med 2003;348(15):1425-34. 
27. Ouirke W, Cahill M, Perera K, Sargent J, Conway J. Warfarin prevalence, indications for use and haemorrhagic events. Ir Med J 2007;100(3):402-4.

28. Ansell J, Jacobson A, Levy J, Völler H, Hasenkam JM, International Self-Monitoring Association for Oral Anticoagulation. Guidelines for implementation of patient self-testing and patient self-management of oral anticoagulation. International consensus guidelines prepared by International Self-Monitoring Association for Oral Anticoagulation. Int J Cardiol 2005;99(1):37-45.

29. Menéndez-Jándula $B$, Souto JC, Oliver $A$, et al. Comparing selfmanagement of oral anticoagulant therapy with clinic management: a randomized trial. Ann Intern Med 2005;142(1):1-10.

30. Mörsdorf S, Erdlenbruch W, Taborski U, et al. Training of patients for selfmanagement of oral anticoagulant therapy: standards, patient suitability, and clinical aspects. Semin Thromb Hemost 1999;25(1):109-31.

31. Gadisseur APA, Kaptein AA, Breukink-Engbers WGM, van der Meer FJM, Rosendaal FR. Patient self-management of oral anticoagulant care vs. management by specialized anticoagulation clinics: positive effects on quality of life. J Thromb Haemost 2004;2(4):584-91.

32. Baydın A, Karataş D, Güven H, Doğanay Z, Yardan T. Retrospective evaluation of patients used warfarin admitted to emergency department. Turk J Emerg Med 2006;6(2):56-9.

33. Canobbio MM. Mosby's Handbook of Patient Teaching. 3rd ed. USA: Mosby Inc. or Elsevier Inc, 2006.

34. Küçükkaya R. Oral Antikoagülan (Warfarin-Coumadin) Tedavi Hasta Kılavuzu. İstanbul: Eczacıbaşı, 2005. 